\title{
Contesting localisation in interfaith peacebuilding in northern Nigeria
}

Accepted for publication in Oxford Development Studies 22 ${ }^{\text {nd }}$ April 2020.

Dr Portia Roelofs a *

a St Anne's College, Oxford

portia.roelofs@st-annes.ox.ac.uk

\section{Author bio:}

Dr Portia Roelofs is Clayman-Fulford Junior Research Fellow in Politics and Political Thought at St Anne's College, Oxford. She has degrees from Oxford, SOAS and the LSE. Her research is on development and politics in Africa, with a focus on Nigeria.

\section{Word Count:}

7980

\section{Acknowledgements:}

I am grateful to the organisers and participants at the Nigerian Politics panel of the African Studies Association UK conference at the University of Birmingham, September 2018 for their comments and feedback. The comments of the editor, the associate editor and two anonymous reviewers were helpful in re-orienting and clarifying the ideas in this paper. Thanks must go to Sule Buba for ongoing inspiration, and Luisa Enria for astute feedback.

\section{Contesting localisation in interfaith peacebuilding in northern Nigeria}

\begin{abstract}
:
Amidst a 'local turn' in peacebuilding, donors have seized on the idea of 'localising' peacebuilding programmes, bringing in actors who have local knowledge and connections in order to make interventions more context-sensitive. Yet programmes premised on the fractiousness of Muslim-Christian relations, as many in northern Nigeria are, are inevitably
\end{abstract}


absorbed into over-arching narratives of global civilisational encounter. How does the local turn play out in this context of heightened international sensitivities? Drawing on the critical peacebuilding literature, this article analyses the origins of USAID's push to localise its interfaith peace-building efforts in northern Nigeria, and the ambivalence of categorises like 'local' and 'international' in its subsequent partnership with the Kaduna-based Interfaith Mediation Centre on the TOLERANCE programme. While the categories of local and international are indeed contested and fluid, there are limits to how far local partners can successful leverage these ideas in the context of unequal power relations.

Keywords: donor partnerships, local turn, interfaith, peacebuilding, Nigeria. 


\section{Introduction}

"While interfaith relations in Nigeria are in many ways unique" note Mustapha et al (2018, 344) in the book Creed \& Grievance: Muslim-Christian Relations \& Conflict Resolution in Northern Nigeria, "they have long been deeply connected to the rest of the world." The contours of this international engagement are constantly shifting. From the $9^{\text {th }}$ century onwards, what is now Nigeria has attracted attention from external religious actors looking to promote first Islam (N. Alkali 1993; Hiribarren 2017) and then Christianity (Sanneh 1997; Ehrhardt 2018, 84). From the Maitatsine uprising in Kano in the 1980s (Danjibo 2009), to conflict between communities in and around Jos (Best and Rakodi 2011; Higazi 2011; Krause 2017) and Kaduna (Ibrahim 1991; Angerbrandt 2011; Wapwera and Gajere 2017), to the declaration of an Islamic state by Boko Haram (Adesoji 2010; Aghedo and Osumah 2012; Kate Meagher and Mustapha 2020), the country continues to experience communal conflict in which religion plays an apparently central role. In this context a new terrain for international intervention into Nigeria's religious life has emerged: peacebuilding interventions which seek to address the terms of engagement and relationship between adherents of different religions. Outside actors, in the form of bilateral donors and international organisations including the United States Institute for Peace ${ }^{\mathrm{i}}$, the Swiss-based Centre for Humanitarian Dialogue ${ }^{\mathrm{ii}}$, Peace Direct ${ }^{\mathrm{iii}}$ and the United Nations Development Programme ${ }^{\mathrm{iv}}$, are increasingly interested in promoting interfaith peacebuilding in the country, particularly in the poorer, Muslim-dominated north of the country ${ }^{\mathrm{v}}$.

In aspiring to mould the everyday social relations of beneficiaries, interfaith peacebuilding programmes based on social contact ${ }^{\mathrm{vi}}$ require an intimate understanding of how religious populations in conflict-affected areas see the world (Harpviken and Røislien 2005). Amidst a broader 'local turn' in peace-building, donors have seized on the idea of 'localising' 
peacebuilding programmes, bringing in actors who have local knowledge and connections in order to make interventions more context-sensitive (Mac Ginty and Richmond 2013). Yet, programmes premised on the fractiousness of Muslim-Christian relations are inevitably absorbed into over-arching narratives of global civilisational encounter (Mustapha 2018). US officials charged with peacebuilding have described northern Nigeria as "vitally important because it sits directly on the Muslim-Christian divide, with major implications for the global war on terror." (Leo 2009) How does the local turn play out in this context of heightened international sensitivities?

This article explores the tensions between the local turn and international imperatives in the day-to-day interactions between Western-based funders of interfaith peacebuilding programmes and their local partners: in the struggles to win funding, to enforce monitoring and evaluation regimes and to respond to higher sources of accountability and strategic programming (Kappler 2015; Hughes 2015; Paffenholz 2015). Yet they reflect deeper issues at the heart of the localisation agenda. Even as donors declare local agency to be desirable in peacebuilding efforts, the structural conditions of their relationship with implementing partners mean unequal power relations are reproduced (Hughes, Öjendal, and Schierenbeck 2015; Ginty 2015).

This article situates the local turn in interfaith peacebuilding in its longer historical and institutional context. It sketches how a major donor's search for local partners in inter-faith peacebuilding in northern Nigeria was the result of at least two decades of mounting American geopolitical interest in religious relations in the country. It focuses on the Training of Leaders on Religious and National Co-Existence (TOLERANCE) project which ran for 5 years from 2012. Funded by USAID, TOLERANCE aimed to build peace by deepening trust and relationships between Muslims and Christians in six northern states: Kaduna, Kano, Bauchi, 
Plateau, Sokoto, and Borno ${ }^{\text {vii }}$. (USAID 2015, 1) It was implemented by the Interfaith Mediation Centre (IMC), a Nigerian-run peacebuilding organisation founded in Kaduna in 1995 by a pastor and imam whose own story of post-conflict reconciliation earned them an international profile.

The article starts by reviewing the local turn in peacebuilding (Mac Ginty and Richmond 2013; Ginty 2015) and ensuing debates over defining the 'local' and 'international' (Leonardsson and Rudd 2015; Hughes, Öjendal, and Schierenbeck 2015) Whilst there is now a consensus that we should conceive of local as a contested and fluid category (Kappler 2015; Hughes, Öjendal, and Schierenbeck 2015; Paffenholz 2015) I draw out questions over the limits to this fluidity in the face of overarching structural power inequalities, asking who gets to decide the boundaries of what counts as 'too local' and 'not local enough'. The case study of TOLERANCE and the IMC is introduced, followed by a brief overview of the landscape in which interfaith encounter has taken place in northern Nigeria in recent decades. The article then analyses how USAID and the IMC leveraged ideas of the local and the international in their interactions, and the conflicts this entailed. The analysis draws on publicly available policy documents from various US and Nigerian organisations working on interfaith peacebuilding, which were subjected to a thematic analysis, including USAID evaluation documents, IMC reports, and US Government cables released via Wikileaks. The final section considers how demands for localisation sit uneasily with the realities of successful Nigerianled organisations which combine authority to speak on local issues with a global reach. The question of what effect these relational dynamics have on the efficacy of peacebuilding programmes and their wider effects is worthy of further research but lies beyond the scope of this paper. 


\section{The local turn in peacebuilding:}

Since the early 1990s there have been a push to localise peacebuilding is part of a larger 'local turn'(Mac Ginty and Richmond 2013). Practitioners and scholars rejected elite peacebuilding initiatives, critiquing the previously dominant liberal peacebuilding agenda for being remote from realities on the ground (Höglund and Orjuela 2012; Mac Ginty 2014). Liberal peacebuilding was shaped by the 'failed states' paradigm and as such was highly sceptical towards the local politics of non-Western states, casting it as "backward and irrational" and thus not worthy of engagement (Hughes, Öjendal, and Schierenbeck 2015, 820). Critical scholars sought to invert top-down models of elite-centred peacebuilding and transcend the "artificial civil society that is dependent on international interveners and disconnected from local communities" (Popplewell 2019, 129). International actors increasingly sought to identify and engage with authentic "citizen peace-makers" (Curle 1994): local actors who were embedded in their cultural, political and social milieu. In the absence of local ownership “perceptions that such efforts are either 'top down', externally imposed or controlled by the state, are likely to render dialogue efforts less effective." (Maddison and Diprose 2018, 1624) The local turn has thus become the orthodoxy. Localisation has, at least in theory, been at the centre of most donor peace building initiatives since the 1990s, with a spike in the usage of the word 'local' in donor reports from the 2000-2010s (Mac Ginty and Richmond 2013, 771).

More recently attention has turned to debates about how to define and conceptualise the 'local' (Leonardsson and Rudd 2015, 81). The discourse of 'peace from below' risks romanticising the local, assuming it to be "actually or potentially political progressive", whereas more empirically grounded studies reveal instead how "the local itself may be internally contested, oppressive, even violent” (Hughes, Öjendal, and Schierenbeck 2015, 820). A second question

concerns the linking of local-ness to authenticity (Hughes, Öjendal, and Schierenbeck 2015, 
818). Whilst there might be some intuitive criteria of what authenticity means - "being rooted in communities, promoting traditional values, and draw[ing] on customary practices" (Popplewell 2019, 137) perhaps - establishing authenticity is not only difficult but political. A final issue is the imposition of fixed categories, whether the binary of international vs local or Lederach's (1997) three part framework of top, middle range and grassroots actors. The result was that scholars reified the local, and cast it as something unchanging, fixed and homogenous (Enria Forthcoming). Given these complexities there have been efforts within critical peace building to "render more complex the essentialist understanding of the local and the international dichotomy" avoid romanticising, exoticisation and pay closer attention to power relations (Paffenholz 2015, 868).

Scholar have emphasised the way that identities of local and global are constructed, contextual and fluid (Hughes, Öjendal, and Schierenbeck 2015, 821). On the one hand, the label 'local' is "inherently relational", typically defined in relation to larger geographic or political scales like the national or the global. On the other 'local' maybe denote a "a concrete presence" for example with formal claims to local government territories. More broadly, "it may refer to a range of more or less codified relationships, practices and sites that are somehow 'below' the level of the national state.” (Hughes, Öjendal, and Schierenbeck 2015, 818) Stephanie Kappler $(2015,876)$ has drawn attention to the way in which actors often skilfully themselves manage their own identification as 'local': "rather than acting in a static way, actors constantly reposition themselves vis-à-vis the 'local' and 'the global'". Kappler describes this as a process of 'delocalisation' or '(re-)localisation': exemplified by her example of a Bosnian NGOs that alternately sought to foreground their 'local' authenticity but their professionalism which involved a distancing themselves from 'local' signifiers. This process of identity formation can "reflect the agency of actors to position themselves vis-à-vis the interveners" (Kappler 2015, 876-78), showing the space for manoeuvre that exists despite the unbalanced power relations 
between international institutions and those with which they interact in conflict settings. Examples from peacebuilding and beyond attest to the fluidity of claims to being local or an insider (Kusow 2003) and highlight the ways that actors use their ability to identify as local as a resource to pursue certain goals. Local actors, whether widows groups in East Timor (Hughes 2015, 925) or diaspora returnees in Sri Lanka (Höglund \& Orjuela, 2012; c/f Paffenholz, 2015, p. 862), may strategically advertise their 'localness' to the international sphere in order to access "resources as well as some space to define their own peace project" (Mac Ginty and Richmond 2013, 771) or to give them "leverage vis-à-vis national ones." (Hughes, Öjendal, and Schierenbeck 2015, 821)

Whilst these narratives highlight the agency and possibility of leveraging claims to 'local-ness', there remain questions about the limits to fluidity and self-definition. Strategies of selfidentification inevitably come up against external labels, with power relations shaping, but not necessarily determining, the ability to successfully designate certain actors as local or international (Hughes, Öjendal, and Schierenbeck 2015, 821). For example, whilst canny selfpresentation as 'local' may be a source of agency for in-country staff in some contexts (Kappler $2015,881-84)$, the ultimate decision over categorisation often remains in the hands of their international funders, for instance with pay differentials enforced for local and international staff (Paffenholz 2004).

From this literature it is possible to distil a number of general questions about how ideas of local-ness and international-ness are constructed and contested in any particular case. Firstly, in what ways is 'local-ness' constructed as a source of either expertise or authenticity? By whom and to what ends? Secondly, how do different actors identify with the idea of the 'international' and distance themselves from the local? For both the above we can ask about the success and consequences of such positioning. Finally, who gets to decide? Who is the final 
arbiter of these powerful categories? The rest of this article provides a preliminary answer to these questions in the case of one American peacebuilding project in northern Nigeria in the early 2010s. In so doing it extends the study of international connections and inter-religious relations in northern Nigeria into the terrain of peacebuilding and localisation.

\section{Interfaith peacebuilding in northern Nigeria:}

Interfaith peacebuilding interventions like TOLERANCE arrive into a complex social and political context. In Nigeria as a whole there are roughly equal of Muslims and Christians (though numbers are disputed) (Mustapha, Ehrhardt, and Diprose 2018, 119-20). By and large the country boasts an impressive record of religious co-existence (Mustapha 2018), with interreligious encounter forging new hybrid religious forms (Peel 2000) and complementary economic arrangements (Kate Meagher 2009; 2018). Across the north, Muslims have historically been numerically and politically dominant (N. Alkali, Monguno, and Mustafa 2012), with Christians a significant minority (Roelofs 2017; Ehrhardt 2018). Religious identities continue to shape debates about citizenship, federalism and legal pluralism (Kendhammer 2016; Hoechner 2018) and are routinely manipulated by elites for personal and political gain, (Ibrahim 1991; Omotosho 2014; Ehrhardt 2017; Obadare 2018). The 1999 constitution of the Fourth Republic guarantees the right to practice one's religion freely and enshrines the state's secular status (Tar and Shettima 2010). In practice religion intertwines with ethnicity, place of origin and linguistic group to create complex and overlapping inequalities, which change not only from state to state, but local government to local government (Angerbrandt 2011; Mustapha 2014; Fourchard 2015). Peacebuilders aiming to overcome negative interreligious attitudes must recognise the structural insecurities that feed them (Nolte, Danjibo, and Oladeji 2009).

The religious landscape is shaped simultaneously by domestic and international forces, and the 
interaction between the two. On the one hand, religion is one of Nigeria's more influential international exports (Adogame 2004). On the other, global narratives of religious encounter are inevitably woven into local histories of interreligious grievance, amplifying tensions (Ibrahim 1991; Ajibuah 2010). At times, the insertion of 'international' actors and events into northern Nigeria's fractious religious landscape has at times peaked interfaith tensions, such as bloody riots following the preaching of German evangelist Reinhard Bonnke in Kano in 1991 (Ojo and Lateju 2010, 33-34), a Christian journalist's comments about the Miss World beauty pageant in Kaduna in 2002 (Angerbrandt 2011, 26), and the publication of Danish cartoons depicting the Prophet Mohammad in 2006 (Omotosho 2014, 134-35).

In response violent episodes there have been successive initiatives to promote interfaith peace and harmony (Ibrahim 1991, 128). These include presidential initiatives like the federallyfunded Advisory Council on Religious Affairs (ACRA), set up in July 1987 by General Babangida (Kwaja 2009) and the Nigeria Inter Religious Council (NIREC) created by then President Obasanjo in response to religious riots over sharia law in Kaduna State in 2000 (Angerbrandt 2011; WFDD 2018). Other Christian-Muslim peacebuilding forums, like the Justice Peace and Reconciliation Movement based in Jos and the Bridge Builders in Kaduna (Ojo and Lateju 2010, 35-36), are more rooted in neighbourhoods and communities and continue the ongoing work of "everyday peace" (Mustapha et al. 2018, 309). . The Kafanchan Peace Declaration of 2017, for example, cites 25 white papers, commissions and initiatives that sought to resolve conflict between communities in southern Kaduna between 1979 and 2015 (Centre for Humanitarian Dialogue 2016, 7). Actors like the local government officials and community leaders who signed up for the Kafanchan Peace Declaration are local compared to the chairs of NIREC, the Sultan of Sokoto and the national Chairman of the Christian Association of Nigeria, but may still be elite vis-à-vis the constituencies they represent. Thus, in northern Nigeria's complex peacebuilding landscape we see the same blurring between 
different categories of actors identified above by the 'local turn' literature and its critics.

\section{Introducing the case study: IMC and TOLERANCE}

The Interfaith Mediation Centre (IMC) was founded in 1995 by Pastor James Wuye and Imam Muhammad Ashafa. The men had been involved in inter-religious violence in Kaduna in 1992 on opposing sides, both incurring heavy losses in the process. Ashafa lost two brothers and a teacher to religiously motivated violence and Wuye was severely injured, eventually losing his hand. Gradually, they built up a relationship of trust and their story has since been circulated around the world as an example of interfaith reconciliation (Wuye and Ashafa 1999). Through their work at the IMC they built a reputation as leading peace workers in northern Nigeria. By 2005 they had received seed funding from the United States Institute for Peace to expand their operations beyond Nigeria (USIP 2017).

The IMC was selected by USAID, via its Nigeria Peace and Democratic Governance Office to implement the $\$ 4.6$ million TOLERANCE programme over 5 years from October 2012. The programme's stated aims were to "deepen faith in order to deepen understandings of peace, enhance trust and relationship building, and strengthen early warning, conflict prevention and mediation." (USAID 2015, 1,13) In line with social-contact theory, the TOLERANCE programme was premised on 'close interactions' between religious actors as a route to peace (IMC 2017, 9), as embodied in the founding narrative of the IMC itself (IMC 2016, 52).

"The IMC training and dialogue platform for engagement provides a means for close interaction between Christian and Muslims and between ethnic groups thereby increasing the level of trust and peaceful co-existence among them. Training, dialogue, and engagement opened up avenues for close interactions, building relationships, and restoring communities.” (USAID 2015, 4-5) 
The programme organises "joint activities and programmes ... [in order to] enhance trust" and "change the negative perceptions of both Christians and Muslims", including mediated workshops and facilitating dialogue (USAID 2015, 4-5). The TOLERANCE programme build on a pre-existing USAID network of Conflict Mitigation and Management Regional Councils (CMMRCs). These are regional bodies made up of local stakeholders which receive funding from the TOLERANCE programme for monthly meetings (USAID 2015, 13) with the intention that "[t]he growth of these relationships then builds social capital, which helps to bring communities together" (USAID 2015, 12).

\section{Analysing the local and the international in TOLERANCE}

\section{In search of the local:}

This section looks at how the TOLERANCE programme originated from a desire within the US government to engage with 'local actors' in Nigeria, driven by both the broader local turn in peacebuilding and geopolitical objectives. However, it is necessary to trace its origins to broader American concerns with religious encounter between Muslims and Christians.

Since the 1990s the American administration was under pressure from its own religious freedom organisations to engage with interfaith issues in Nigeria. Letters from the chair of the United States Commission for International Religious Freedom (USCIRF) to successive American Presidents starting with Clinton in $2000^{\text {viii }}$, raised alarm over the state of religious freedom in Nigeria with a focus on the marginalization of Christians in the twelve states that adopted sharia law. These concerns predate but were intensified by global security concerns after the September $11^{\text {th }}$ attacks on the World Trade Centre in New York, and the ensuing War on Terror led by George W Bush. By 2002 Nigeria was on the United States Commission for International Religious Freedom's Watch List (USCIRF 2006, 1). The US Embassy in Nigeria 
expressed concerns in 2005 about the "fertile ground for religious extremism, especially in Muslim northern Nigeria"ix. An array of US-funded development and peacebuilding schemes were justified under the banner of 'combating extremism': from basketball leagues, study visits, to Magama, a Hausa-language magazine for young people ${ }^{\mathrm{x}}$.

In 2009 the USCIRF called for the US Government to designate the Nigeria as a country of particular concern under the International Religious Freedom Act of 1998 on the grounds that the Nigerian government was unwilling to act to prevent and was tolerating "particularly severe violations of religious freedom" (USCIRF 2009, 63). As Chair of USCIRF, Leonard A. Leo, said in his address to the Congressional International Religious Freedom Caucus in 2009, "Nigeria is vitally important because it sits directly on the Muslim-Christian divide, with major implications for the global war on terror." (Leo 2009) Thus it became a stated goal of American foreign policy that Muslims and Christians in Nigeria should be engaged in interfaith dialogue and that this dialogue should achieve certain ends.

At the same time as US government actors were emphasising the international ramifications of interfaith relations in Nigeria, the USCIRF emphasised the importance of 'the local' in making sense of the threat and recommendations to achieve better relations. The Commission's recommendations for diplomacy focussed on increasing the presence of the U.S. Government in northern Nigeria and achieving a greater penetration of local spaces and conversations by its international staff. They urged the establishment of a US consulate or other official presence in Kano or another northern city, and to expand the capacity of the Voice of America Hausa service. The push for greater assimilation into local knowledge was repeated in USCIRF's recommendation that the government should "provide Embassy and Consulate staff with appropriate local language skills, and requiring political and public affairs officers to regularly 
travel throughout Nigeria" (USCIRF 2009, 63) US embassy staff were keen to harness and support local organisations $^{\mathrm{xi}}$ (USCIRF 2006, 6).

The US government's desire to engage with local actors and benefit from local knowledge was particularly emphasised in its statements regarding interfaith and peacebuilding work. Based on past experience local actors were seen as privileged in terms of micro-level knowledge and heightened acceptability to target beneficiaries. A 2009 document reviewing the lessons learnt from USAID's past interfaith work, stressed the way that partnering with the IMC gave USAID access to the local knowledge and sensitivity: "[1]ocal established partners are invaluable." It explains that the IMC:

\footnotetext{
"was attractive to USAID because it is a local organization already engaged in conflict resolution programming and had a good understanding of local nuances and dynamics, including ethnic tensions and local interpretations of Christianity and Islam. Without a local link, one might inadvertently misunderstand the situation and increase tensions through poor programming." (USAID 2009, 25)
}

The reviewers conclude that "[IMC]'s knowledge and sensitivity to local conditions was crucial to the program's success." (USAID 2009, 25)

Beyond the pressure exerted by USCIRF, the need for USAID's activities in Nigeria to tap into 'local' knowledge and networks, was shaped by even more high-level forces in the US government. Even the most inconsequential seeming moments in the relationship between USAID and 'local' actors carry the imprints of geo-political prerogatives. A banal example: before TOLERANCE, USAID ran a peacebuilding programme called CALM which involved setting up 'peace clubs'. These were after-school sports activities for young people from groups that had been involved in inter-communal violence. As this work was ongoing, US President Barack Obama was seeking to assert a clean break with his predecessor's hostile engagements 
with the Middle East and establish "a new beginning between the United States and Muslims around the world ... one based upon the truth that America and Islam are not exclusive and need not be in competition." ${ }^{\text {xii }}$ In a much heralded speech at Cairo University on $4^{\text {th }}$ June 2009 , the President sought to heal the wounds of the September $11^{\text {th }}$ terrorist attacks and subsequent wars in Afghanistan and Iraq: after quoting from the Quran he explained that the US would undertake "service projects" at home and abroad "to bring together Christians, Muslims, and Jews."xiii

Soon afterwards, a cable was sent from Washington to US diplomatic stations around the world encouraging them "to plan an Interfaith Day of Service to commemorate 9/11 that would send a message of goodwill, cooperation, and shared interest to their host countries and their religious communities."xiv The Abuja office took up this invitation and in October of that year sent 30 inter-agency staff to one of CALM's peace-clubs in Jos to redecorate their basketball court. The embassy noted that Jos "has special symbolic value as a venue because of politicallyinspired communal violence in November 2008 that left several hundred people dead."xv This demonstrates the complexity of the international/local nexus as it plays out in northern Nigeria: in commemoration of an act of terrorism that sparked the War on Terror, the US President sends out a global call for interfaith projects. In response, the US embassy in Abuja, a subordinate but still 'international' actor, draws on pre-existing relationships to enact their familiarity with 'authentic' local actors.

Thus, when it came to initiate the next round of programming for interfaith activities in Nigeria from 2010 onwards, USAID had reason to seek out potential partners who had strong claims to local knowledge and authenticity. One of the benefits of local knowledge was that it allowed the IMC be "engaged with both sides through a culturally-sensitive approach, utilizing the traditions of conflict-affected communities." (USAID 2009, 26) Thus local knowledge in the 
form of "traditions of conflict-affected communities" and "local interpretations of Christianity and Islam" was seen as a vital tool for improving the implementation of USAID's broader policy agenda. Responding to USAID's announcement of that it would partner with the IMC to implement the TOLERANCE programme, the USCIRF said it was "encouraged that the U.S. government has begun to implement some of USCIRF's long-standing recommendations on Nigeria" (USCIRF 2011,2). Thus, in the case of USAID's programming in northern Nigeria demand for the 'local' was sustained by more international imperatives linked to America's global strategy.

\section{Identifying with the international:}

Whilst USAID foregrounded the IMC's position as a 'local' organisation to meet the demands of other American Government actors, the IMC's self-presentation by contrast emphasises its international reach. Its mission is "to create a peaceful society through non-violence and strategic engagement in Nigeria and beyond"xvi [italics added]. Likewise, the organisation's training manual proudly refers to its history "promoting healing and trust-building activities in Sudan, South Sudan, Sierra Leone, Malaysia, Chad, Bosnia, Burundi, Kenya, Uganda, Croatia, Northern Ireland and the US." (IMC 2014, 1) Indeed over the course of TOLERANCE programme, the IMC strengthened its connections with transnational organisations, participating from 2013 in the United Religions Initiative's Cooperation Circle and leading Nigeria's commemoration of the Rwandan genocide in $2016^{\text {xvii }}$.

The co-founders themselves enjoyed national and international recognition for their peacebuilding achievements from the late 1990s onwards. In 1999 they published a book together, The Pastor and the Imam: Responding to Conflict. By 2005 their efforts had earned them awards from the Tanenbaum Centre for Inter-Religious Understanding in New York and both were elected to Ashoka Fellowships in $2006^{\text {xiii }}$. The story of Wuye and Ashafa's 
transformation from animosity to friendship was turned into a documentary film titled 'The Imam and the Pastor' made by British not-for-profit FLTfilms and the United States Institute of Peace. With premieres in the UN HQ in New York and British Parliament in 2008, the film earned endorsements from the then Archbishop of Canterbury and Oprah Winfrey ${ }^{\text {xix }}$, and was translated into Arabic ${ }^{\mathrm{xx}}$. In 2010 FLTfilms released a follow-up film, An African Answer. ${ }^{\mathrm{xxi}}$

This international profile was part of why USAID selected IMC for the TOLERANCE programme. By the start of the project in 2012 the IMC was one of the most high-profile Nigerian civil society organisations, and its chairmen had a track record of working with foreign NGOs. Prior to the $\$ 4.6$ million agreement with USAID, IMC had received funding from governmental development agencies, international organisations and the UN. ${ }^{x x i i}$ It was described by USAID evaluators as "a significant player in the fields of human rights, religion and social development at the community, state, national and international levels." (USAID $2015,10)$

Within the TOLERANCE programme, the roles of USAID and the IMC in many ways shaped by standard dynamics donor recipient dynamics. As the donor, USAID's Nigeria Peace and Democratic Governance Office awarded funding for the programme (USAID 2015, 1). IMC was subject to monitoring and evaluation by other arms of USAID, which had access to considerable technical and human resources to scrutinise how IMC was implementing the programme, as well as being able to call on networks of oversight from higher levels within USAID (USAID 2015, iv). Yet, the ability of USAID to hold the IMC accountable for its contributions to the TOLERANCE programme faced some hurdles. 


\section{Who decides?}

The TOLERANCE project not only tied the IMC to USAID, but also created relationships with other training and capacity building organisations based in the United States. USAID called in the University of Massachusetts, Boston (UMASS) and Public Conversation Project (PCP) to "strengthen the sustainability of IMC to adequately manage donor funding" and "play an advisory, mentoring and guiding role.” (USAID 2015, 1, 38). USAID's push for capacity building speaks to the ambivalence of localisation efforts: USAID's local partners must be able to comply with international accounting and auditing standards, whilst maintaining their 'local' character. USAID's depended on the cooperation of local actors, like IMC, change their internal operations in order for USAID to meet their own goals.

Indeed, the capacity building did not work out as planned. "Little has been achieved with these partnerships", notes the mid-term report (USAID 2015, 4). The IMC displayed little interest in taking up or embedding the capacity building on offer. Where UMASS was charged with ensuring the programme's financial accountability by reviewing monthly financial reports prepared for USAID, the University was able to access barely a quarter of the reports (USAID 2015, 38). USAID evaluators expressed their concern that the IMC has not been sufficiently appreciative of the value of capacity building or its need to reform itself in line with 'international' models of how local partners should operate:

"The TOLERANCE program has given IMC a unique opportunity to develop its capacity. It does not appear to be taking advantage of the resources made available for this purpose from UMASS and PCP, due to its tendency to maintain its current business practice.” (USAID 2015, 4)

Despite UMASS receiving $\$ 738,000$ to support IMC, USAID acknowledged that UMASS was "essentially left [only] with persuasion as a tool for change" (USAID 2015, 38). More 
generally, despite USAID's control over funding and agenda-setting, the organisation struggled to maintain control over TOLERANCE. Core initiatives of the programme, like the Early Warning Early Response (EWER) system for alerting authorities to potential sources of local conflict, were apparently neglected by TOLERANCE staff and the electronic system went under-used (USAID 2015, 5-6). As the IMC evaded USAID's attempts at monitoring and evaluation, the evaluating team concluded that it was unable to discern how USAID funds were being used or whether it was achieving any impact. (USAID 2015, 6)

While the question of programme efficacy is beyond the scope of this analysis, part of the problem may have been that the IMC was more 'international' than its US partners had bargained for. "[A]ctual management of the TOLERANCE program", the mid-term report notes, "is not a focus of the leadership. This is partly due to the frequent trips abroad that senior members take when they are invited to share the IMC story". The pastor and the imam whose story helped build their organisation's claim to local authenticity "are mainly outward looking, that is, outside Nigeria and are internationally known" with travel said to be consuming approximately $25 \%$ of their time (USAID 2015, 40-41). Indeed, that year the co-founders overseas speaking engagements included the Harvard University Centre for African Studies ${ }^{\text {xxiii }}$.

The mid-term report concludes with an ultimatum from the 'international': "IMC needs to change with the times or be left behind. IMC has a proven capacity for addressing interfaith conflict, but so do other organizations. Unless it is willing to adopt needed change it will be left behind." (USAID 2015, 39) The IMC “must meet the requirements of international funding organizations in order for it to grow, mature and expand its operations in a competent and transparent manner." (USAID 2015, 43) Here, the IMC's status as local is inverted, as something that holds the organisation back from 'changing with the times'. USAID's evaluators note that the claim to 'local' knowledge that IMC leveraged to win funding is not 
unique to IMC. The evaluation report demonstrates the ultimate power of the international over the local, as well as USAID's position as ultimate arbiter over who is too local and who is not local enough.

Ultimately, in this case, the 'international' retained the ability to pick between competing local actors, to find those that are most willing to meet their needs.

Thus, interfaith programmes in northern Nigeria are shaped by complex negotiations between the international and the local, where both terms are leveraged by different players to achieve certain ends. Returning to the three framing questions in the first section, this article has shown first how USAID constructed the local as a source of expertise, though this search for the local can be traced back to changing geo-political agendas that have driven America's foreign policy since the 1990s. Whilst the IMC was selected as a partner due to its claim to local expertise and authenticity, via its founding story, it nonetheless held tight to a vision of itself as a solidly international actor. IMC founders travelled frequently and for them the TOLERANCE project was only one of many competing activities rather than a sole focus. IMC's ability to present itself as simultaneously local and international helped initially secure its involvement in TOLERANCE but was also a source of tension when it came to implementing the programme. On the final question of who has the power to set the limits of the local and international, we see USAID was able to discipline its local partner for a failure to bend to international models of best practice, and for being 'too international'.

\section{Conclusion:}

Interfaith peacebuilding has become an important site of international intervention into northern Nigeria's religious landscape. The interactions between USAID and the IMC as part of the TOLERANCE programme demonstrates the complexity of the categories 'local' and 'international' which have taken on heightened salience following the local turn in 
peacebuilding (Paffenholz 2015; Hughes, Öjendal, and Schierenbeck 2015). The analysis confirms the relevance of ideas like 'processual localism' (Kappler 2015), highlighting the fluid and contested meanings of such categories, as well as the way they can be leveraged in apparently contradictory ways in the context of donors' searches for a romanticised vision of context-specific knowledge and authenticity. However, the article also shows that the agency of Nigerian actors to self-present as both local and international is limited as they remain subordinate partners in their engagement with donors.

The TOLERANCE programme came to an end in March 2018, having trained upwards of 8000 civic leaders across seven states in Nigeria (Salau 2018). The IMC continues to act as a broker in emerging conflicts in Nigeria, including that between pastoralists and farmers in Nigeria's North and Middle Belt. At the same time, the international profile of its founders has continued to grow, with Wuye and Ashafa awarded the 2017 Intercultural Innovation Award, a joint venture of the BMW Group and the United Nations Alliance of Civilisations, at a prize ceremony in New York ${ }^{\mathrm{xxiv}}$. The uneasiness with which these international networks fit with what USAID demanded of its local partners raises further questions about the localisation agenda. Perhaps, there is something jarring about the idea of 'local' partners with 'local expertise' managing a portfolio of overseas projects and attending speaking engagements at Harvard. Not only are 'local' partners expected to have deep roots, but these roots should hold them in place: local should not be internationally mobile.

This article did not seek to asses the efficacy of the TOLERANCE programme. Nonetheless, the findings do offer some insight for those interested in whether the localisation agenda leads to more effective programming: that is simply to note that the push for donors to engage local actors is driven by a wider range of political and institutional motives than simply to improve operational outcomes. As seen in the case of USAID in Nigeria, donors agencies may seek out 
local partners in order to back up presidential gestures of good will or as part of an agenda to penetrate more deeply into societies seen as crucial to the future of global conflicts. Future research could investigate whether these diverse and potentially contradictory imperatives lead to better peacebuilding programmes.

As actors within Nigeria and elsewhere grapple with the country's evolving conflicts, the localisation agenda continues. Under the banner of Community Initiatives to Promote Peace (CIPP), the successor programme to TOLERANCE has been earmarked a budget of $\$ 15$ million. The notice of funding opportunity for this new five-year programme articulates a familiar desire for local expertise and authenticity:

"the Recipient should work with credible local groups/organizations known to communities to ensure buy-in and the success of the activity. ... It is expected that these local groups will have much closer ties to the targeted communities and are perceived as more legitimate and thus will be more effective in mediating disputes at the community level before they lead to wider violence." ${ }^{\mathrm{xxv}}$

It remains to be seen whether these ongoing engagements will replicate the same tensions around the ideas of local and international as seen in the TOLERANCE programme and what effect these tensions have on interfaith relations in northern Nigeria. 


\section{References}

Abrams, Elliot. 2001. "Letter Asks President Bush to Raise Religious-Freedom Issues With Nigerian President." United States Commission on International Religious Freedom. May 11, 2001. http://www.uscirf.gov/advising-government/government-correspondence/letter-askspresident-bush-raise-religious-freedom.

Adesoji, Abimbola. 2010. "The Boko Haram Uprising and Islamic Revivalism in Nigeria." Africa Spectrum 45: 95-108.

Adogame, Afe. 2004. "Contesting the Ambivalences of Modernity in a Global Context: The Redeemed Christian Church of God, North America." Studies in World Christianity 10 (1): 25-48. https://doi.org/10.3366/swc.2004.10.1.25.

Aghedo, Iro, and Oarhe Osumah. 2012. "The Boko Haram Uprising: How Should Nigeria Respond?" Third World Quarterly 33: 853-69. https://doi.org/10.1080/01436597.2012.674701.

Ajibuah, B. J. 2010. "Urban Crises and Rental Values Differential in Kaduna Metropolis." FUTY Journal of the Environment 5 (1): 43-50-50. https://doi.org/10.4314/fje.v5i1.63770.

Alkali, Nur. 1993. Islam in Africa: Proceedings of the Islam in Africa Conference. Ibadan; St. Helier, Jersey, Channel Islands, UK: Spectrum Books ; Safari Books.

Alkali, Nur, Abubakar Kawu Monguno, and Ballama Shettima Mustafa. 2012. "Overview of Islamic Actors in Northeastern Nigeria." NRN Working Paper 2. Oxford: Nigeria Research Network, Queen Elizabeth House, University of Oxford.

Allport, G, K Clark, and T Pettigrew. 1954. The Nature Of Prejudice. Cambridge, MA: Perseus Books.

Angerbrandt, Henrik. 2011. "Political Decentralisation and Conflict: The Sharia Crisis in Kaduna, Nigeria." Journal of Contemporary African Studies 29 (1): 15-31. https://doi.org/10.1080/02589001.2011.533057.

Best, Shedrack Gaya, and Carole Rakodi. 2011. "Violent Conflict and Its Aftermath in Jos and Kano, Nigeria: What Is the Role of Religion?" Working Paper. University of Birmingham. http://www.religionsanddevelopment.org/files/resourcesmodule/@random454f80f60b3f4/133 0691480_working_paper_69.pdf.

Centre for Humanitarian Dialogue. 2016. "The Kafanchan Peace Declaration." https://www.hdcentre.org/wp-content/uploads/2016/08/Kafanchan-Peace-Declaration23.03.2016.pdf.

Curle, Adam. 1994. "New Challenges for Citizen Peacemaking." Medicine and War 10 (2): 96-105. https://doi.org/10.1080/07488009408409148.

Danjibo, N. D. 2009. "Islamic Fundamentalism and Sectarian Violence: The 'Maitatsine' and 'Boko Haram' Crises in Northern Nigeria." In IFRA Conference on Conflict and Violence in Nigeria. Zaria, Nigeria: Institut Francais de Recerche en Afrique \& Institute for Development Research, Zaria. internal-pdf://Danjibo-1072086017/Danjibo.pdf.

Ehrhardt, David. 2017. "Indigeneship, Bureaucratic Discretion and Institutional Change in Northern Nigeria." African Affairs.

.2018. "The Significant Minority: Christians and Christianity in Northern Nigeria." In Creed \& Grievance: Muslim-Christian Relations \& Conflict Resolution in Northern Nigeria, edited by Abdul Raufu Mustapha and David Ehrhardt, 83-107. S.l.: Boydell and Brewer.

Enria, Luisa. Forthcoming. "Unsettled Authority and Humanitarian Practice: Reflections on Legitimacy from Sierra Leone's Borderlands." Oxford Development Studies (this issue).

Fourchard, Laurent. 2015. "Bureaucrats and Indigenes: Creating and Bypassing Certificates of Origin in Nigeria." Africa 85 (1).

Ginty, Roger Mac. 2015. "Where Is the Local? Critical Localism and Peacebuilding." Third World Quarterly 36 (5): 840-56. https://doi.org/10.1080/01436597.2015.1045482.

Harpviken, Kristian Berg, and Hanne Eggen Røislien. 2005. "Mapping the Terrain: The Role of Religion in Peacemaking." State of the Art Paper. Oslo: PRIO - International Peace Research Institute Oslo.

Higazi, Adam. 2011. The Jos Crisis: A Recurrent Nigerian Tragedy. Abuja: Friedrich-Ebert-Stiftung. 
Hiribarren, Vincent. 2017. A History of Borno: Trans-Saharan African Empire to Failing Nigerian State. London: C Hurst \& Co Publishers Ltd.

Hoechner, Hannah. 2018. Quranic Schools in Northern Nigeria: Everyday Experiences of Youth, Faith, and Poverty. 1st ed. Cambridge University Press. https://doi.org/10.1017/9781108348270.

Höglund, Kristine, and Camilla Orjuela. 2012. "Hybrid Peace Governance and Illiberal Peacebuilding in Sri Lanka." Global Governance: A Review of Multilateralism and International Organizations 18 (1): 89-104. https://doi.org/10.1163/19426720-01801008.

Hughes, Caroline. 2015. "Poor People's Politics in East Timor." Third World Quarterly 36 (5): 90828. https://doi.org/10.1080/01436597.2015.1029906.

Hughes, Caroline, Joakim Öjendal, and Isabell Schierenbeck. 2015. "The Struggle versus the Song the Local Turn in Peacebuilding: An Introduction." Third World Quarterly 36 (5): 817-24. https://doi.org/10.1080/01436597.2015.1029907.

Ibrahim, Jibrin. 1991. "Religion and Political Turbulence in Nigeria." The Journal of Modern African Studies 29 (1): 115-36. https://doi.org/10.1017/S0022278X00020760.

IMC. 2014. "IMC Training Manual - Reflective Structured Dialogue: A Dialogic Approach to Peacebuilding." Kaduna: Interfaith Mediation Centre. https://static1.squarespace.com/static/5404f2c1e4b01b550b3ebfba/t/582ede3b46c3c43279185 9a5/1479466565626/REFLECTIVE+STRUCTURED+DIALOGUE+By+IMC.pdf. . 2016. "TOLERANCE Annual Report: October 2015 to September 2016.” Interfaith Mediation Centre.

https://static1.squarespace.com/static/5404f2c1e4b01b550b3ebfba/t/583579a259cc684019c51 d0c/1479899570410/IMC+TOLERANCE+FY+2016+ANNUAL+REPORT+pdf.pdf. . 2017. "TOLERANCE F17 Q2 Report: January - March 2017.” Interfaith Mediation Centre.

Kappler, Stefanie. 2015. "The Dynamic Local: Delocalisation and (Re-)Localisation in the Search for Peacebuilding Identity." Third World Quarterly 36 (5): 875-89. https://doi.org/10.1080/01436597.2015.1025740.

Kendhammer, Brandon. 2016. Muslims Talking Politics: Framing Islam, Democracy, and Law in Northern Nigeria. University of Chicago Press.

Krause, J. 2017. "Non-Violence and Civilian Agency in Communal War: Evidence from Jos, Nigeria." African Affairs 116 (463).

Kusow, Abdi M. 2003. "Beyond Indigenous Authenticity: Reflections on the Insider/Outsider Debate in Immigration Research." Symbolic Interaction 26 (4): 591-99. https://doi.org/10.1525/si.2003.26.4.591.

Kwaja, Chris. 2009. "Strategies for (Re)Building State Capacity to Manage Ethnic and Religious Conflict in Nigeria." Journal of Pan African Studies 3 (3).

Lederach, J.P. 1997. Building Peace: Sustainable Reconciliation in Divided Societies. Washington D.C.: United States Institute of Peace Press. https://gsdrc.org/document-library/buildingpeace-sustainable-reconciliation-in-divided-societies/.

Leo, Leonard A. 2009. Prospects for Justice in Northern and Central Nigeria: Government Responses to Religious Extremism and Root Causes. Washington D.C. . 2011. "USCIRF Letter to President Obama on Egypt, Nigeria, and China." United States Commission on International Religious Freedom. January 14, 2011. http://www.uscirf.gov/advising-government/government-correspondence/uscirf-letterpresident-obama-egypt-nigeria-and-china.

Leonardsson, Hanna, and Gustav Rudd. 2015. "The 'Local Turn' in Peacebuilding: A Literature Review of Effective and Emancipatory Local Peacebuilding." Third World Quarterly 36 (5): 825-39. https://doi.org/10.1080/01436597.2015.1029905.

Mac Ginty, Roger. 2014. "Everyday Peace: Bottom-up and Local Agency in Conflict-Affected Societies." Security Dialogue 45 (6): 548-64. https://doi.org/10.1177/0967010614550899.

Mac Ginty, Roger, and Oliver P Richmond. 2013. "The Local Turn in Peace Building: A Critical Agenda for Peace." Third World Quarterly 34 (5): 763-83. https://doi.org/10.1080/01436597.2013.800750. 
Maddison, Sarah, and Rachael Diprose. 2018. "Conflict Dynamics and Agonistic Dialogue on Historical Violence: A Case from Indonesia.” Third World Quarterly 39 (8): 1622-39. https://doi.org/10.1080/01436597.2017.1374837.

Meagher, Kate. 2009. "Trading on Faith: Religious Movements and Informal Economic Governance in Nigeria.” The Journal of Modern African Studies 47 (03): 397. https://doi.org/10.1017/S0022278X0900398X. 2018. "Complementarity, Competition and Conflict: Informal Enterprise and Religious Conflict in Northern Nigeria." In Creed \& Grievance: Muslim-Christian Relations \& Conflict Resolution in Northern Nigeria, edited by Abdul Raufu Mustapha and David Ehrhardt, 184 222. S.l.: Boydell and Brewer.

Meagher, Kate, and Raufu Mustapha. 2020. Overcoming Boko Haram. James Currey.

Mkandawire, Thandika. 1998. "Crisis Management and the Making of 'Choiceless Democracies' in Africa." In State, Conflict, and Democracy in Africa, edited by Richard A. Joseph. Boulder, Colo.: Lynne Rienner Pub.

Mustapha, Abdul Raufu. 2014. Sects \& Social Disorder: Muslim Identities \& Conflict in Northern Nigeria. Boydell \& Brewer Ltd. .2018. "Introduction: Religious Encounters in Northern Nigeria." In Creed \& Grievance: Muslim-Christian Relations \& Conflict Resolution in Northern Nigeria, edited by David Ehrhardt and Abdul Raufu Mustapha. Rochester, NY: Boydell and Brewer.

Mustapha, Abdul Raufu, David Ehrhardt, and Rachael Diprose. 2018. "Historical Contexts of Muslim-CHristian Encounters in Northern Nigeria." In Creed \& Grievance: MuslimChristian Relations \& Conflict Resolution in Northern Nigeria, 108-35. S.1.: Boydell and Brewer.

Mustapha, Abdul Raufu, Adam Higazi, Jimam Lar, and Karel Chromy. 2018. "Jos: Bottom-up and Top-down Approaches to Peace Building." In Creed \& Grievance: Muslim-Christian Relations \& Conflict Resolution in Northern Nigeria, edited by Abdul Raufu Mustapha and David Ehrhardt, 308-37. Rochester, NY: Boydell and Brewer.

Nolte, Insa, Nathaniel Danjibo, and Abubakar Oladeji. 2009. Religion, Politics and Governance in Nigeria. Birmingham: University of Birmingham. International Development Department.

Obadare, Ebenezer. 2018. Pentecostal Republic. London: ZED Books. https://www.zedbooks.net/shop/book/pentecostal-republic/.

Ojo, Matthews A., and Folaranmi T. Lateju. 2010. "Christian-Musliam Conflict and Interfaith BridgeBuilding Efforts in Nigeria." The Review of Faith \& International Affairs 8 (1): 31-38. https://doi.org/10.1080/15570271003707762.

Omotosho, Mashood. 2014. "Managing Religious Conflicts in Nigeria: The Inter-Religious Mediation Peace Strategy." Africa Development, no. 2: 20.

Ostien, Philip. 2018. "The Muslim Majority in Northern Nigeria: Sects \& Trends." In Creed \& Grievance: Muslim-Christian Relations \& Conflict Resolution in Northern Nigeria, edited by Abdul Raufu Mustapha and David Ehrhardt. Boydell and Brewer.

Paffenholz, Thania. 2004. "Designing Transformation and Intervention Processes." In Transforming Ethnopolitical Conflict: The Berghof Handbook, edited by Alex Austin, Martina Fischer, and Norbert Ropers, 151-69. Wiesbaden: VS Verlag für Sozialwissenschaften. https://doi.org/10.1007/978-3-663-05642-3_8. 2015. "Unpacking the Local Turn in Peacebuilding: A Critical Assessment towards an Agenda for Future Research." Third World Quarterly 36 (5): 857-74. https://doi.org/10.1080/01436597.2015.1029908.

Peel, J. D. Y. 2000. Religious Encounter and the Making of the Yoruba. Bloomington: Indiana University Press.

Popplewell, Rowan. 2019. "Civil Society, Hybridity and Peacebuilding in Burundi: Questioning Authenticity." Third World Quarterly 40 (1): 129-46. https://doi.org/10.1080/01436597.2018.1432347.

Roelofs, Portia. 2017. "Civil Society, Religion and the State: Mapping of Borno and Adamawa, a Stakeholder Analysis." Prepared for the programme "Support to Strengthening Resilience in North-East Nigeria.” Abuja, Nigeria: GIZ Nigeria. 
Salau, Abdullateef. 2018. "Nigeria: Interfaith Centre Trains 8,500 Leaders On Religious Tolerance." Daily Trust, March 2, 2018. https://allafrica.com/stories/201803020810.html.

Sanneh, Lamin. 1997. Crown and the Turban: Muslims and West African Pluralism. Boulder CO: Perseus Book Group.

Scacco, Alexandra, and Shana S. Warren. 2018. "Can Social Contact Reduce Prejudice and Discrimination? Evidence from a Field Experiment in Nigeria." American Political Science Review 112 (3): 654-77. https://doi.org/10.1017/S0003055418000151.

Tar, Usman A., and Abba Gana Shettima. 2010. "Endangered Democracy?: The Struggle over Secularism and Its Implications for Politics and Democracy in Nigeria." http://nai.divaportal.org/smash/record.jsf?pid=diva2:311793.

USAID. 2009. "Religion Conflict and Peacebuilding: An Introductory Programming Guide." Office of Conflict Management and Mitigation. USAID. http://www.partner-religiondevelopment.org/fileadmin/Dateien/Resources/Knowledge_Center/Pnadr501.pdf.

_ 2015. "TOLERANCE Mid-Term Evaluation Report." USAID/Nigeria Monitoring and Evaluation Management Services. USAID/Nigeria. http://pdf.usaid.gov/pdf_docs/PA00KMKD.pdf.

USCIRF. 2006. “Annual Report 2006: Nigeria." Washington D.C.: United States Commission for International Religious Freedom. 2009. “Annual Report 2009: Nigeria." Washington D.C.: United States Commission for International Religious Freedom.

. 2011. "Annual Report Summary: Nigeria at a Glance Summary.” Washington D.C.: Office of Conflict Management and Mitigation, United States Commission on International Religious Freedom.

USIP. 2017. "Nigeria's Imam and Pastor." United States Institute of Peace. September 29, 2017. https://www.usip.org/publications/2017/09/nigerias-imam-and-pastor-faith-front-video.

Wapwera, Samuel Danjuma, and Jiriko Kefas Gajere. 2017. "Ethnoreligious Urban Violence and Residential Mobility in Nigerian Cities: The Kaduna Experience." Research Article. Urban Studies Research. 2017. https://doi.org/10.1155/2017/4624768.

WFDD. 2018. "Faith and Development in Focus in Nigeria." World Faiths Development Dialogue (WFDD) \& Berkeley Centre for Religion, Peace and World Affairs.

Wuye, James Movel, and Muhammad Nurayn Ashafa. 1999. The Pastor and the Imam: Responding to Conflict. Lagos: Ibrash Publications Centre Ltd. 


\section{Endnotes}

${ }^{\mathrm{i}}$ See (Scacco and Warren 2018)

${ }^{i i}$ https://www.hdcentre.org/activities/jos-plateau-state-nigeria/ < accessed 22nd January 2020>

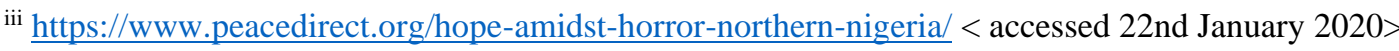

${ }^{\text {iv }}$ https://procurement-notices.undp.org/view_notice.cfm?notice_id=53675 <accessed 22nd January 2020>

v The term northern Nigeria, with northern uncapitalized, is used throughout to refer to the 19 states and Federal Capital Territory which were carved out of the old Northern Region (Ostien 2018, 38). It includes the Middle Belt.

${ }^{\mathrm{vi}}$ Social contact theory, originally developed by Allport et al (1954), states that, under certain conditions, interaction with members of other social groups improves out-group attitudes and reduces prejudice and discriminatory behaviour.

vii It later expanded into Imo in the southeast.

viii See also the letters to presidents Bush (Abrams 2001) and Obama (Leo 2011)

ix Nigeria Abuja. "Nigeria: Combating extremism” Wikileaks cable: 05ABUJA1850_a Dated 28 ${ }^{\text {th }}$ September 2005. https://wikileaks.org/plusd/cables/05ABUJA1850_a.html <Accessed $9^{\text {th }}$ August 2019>

${ }^{x}$ Ibid.

${ }^{x i}$ Initially USCIRF's preferred candidate was the Nigeria's Inter-Religious Council (NIREC) which they urged the U.S. Government to help to expand to state and local levels.

xii Remarks by the President at Cairo University, $4^{\text {th }}$ June 2009 . The White House, Office of the Press Secretary. xiii Ibid.

xiv United States Secretary of State. "Interfaith day of service” Wikileaks cable: 09STATE89406_a 27 $7^{\text {th }}$ August 2009. <Accessed $9^{\text {th }}$ August 2019> https://wikileaks.org/plusd/cables/09STATE89406_a.html

${ }^{x v}$ Nigeria Abuja. “Jos, Nigeria Interfaith day of service” Wikileaks cable: 09ABUJA1943_a Dated 23 ${ }^{\text {rd }}$ October 2009. <Accessed $9^{\text {th }}$ August 2019> https://wikileaks.org/plusd/cables/09ABUJA1943_a.html

${ }^{x v i}$ http://www.imc-nigeria.org/mission/ <Accessed August 8th, 2018>

xvii https://uri.org/uri-story/20160513-interfaith-mediation-centre-commemoration-rwandan-genocide-2016 <Accessed 8th December 2019>

xviii https://www.ashoka.org/en-gb/fellow/mohammed-ashafa <Accessed August 12th, 2019> 
xix https://www.iofc.org/pastor-and-imam-represent-possibility-peace-world-oprah-winfrey < Accessed August 12th, 2019>

${ }^{x x}$ http://adyanfoundation.org/library/documentaries/imam-and-the-pastor/ <Accessed August 10th, 2019>

xxi http://anafricananswer.org/film-info $<$ accessed 22nd January 2020>

xxii British High Commission, European Union, Christian AID United Kingdom, French Embassy, UNICEF, International Republican Institute and UNDP.

xxiii $\underline{\text { https://africa.harvard.edu/event/pastor-and-imam-nigeria-interfaith-strategy-peacebuilding-prospects-and }}$ <Accessed 12th August 2019>

xxiv https://www.iofc.nl/imam-and-pastor-receive-un-award-intercultural-innovation < Accessed 12th August 2019>

${ }^{x x v}$ Nigeria USAID-Abuja. Community Initiatives to Promote Peace (CIPP) Notice of Funding Opportunity Solicitation \# 62072018RFA00005. Page 6-7. October 3rd 2018. https://www.grants.gov/web/grants/viewopportunity.html?oppId=309395 <Accessed 10th August 2019> 